\title{
Developing policy instruments: The transformation of an educational policy intervention
}

\author{
Hongda $\operatorname{Lin}^{1}\left(\mathbb{D} \cdot\right.$ Reijo Miettinen $^{1}$
}

Published online: 24 November 2018

(C) The Author(s) 2018

\begin{abstract}
This paper discusses the change of educational governance by developing and using a theory of policy instrumentality. It is based on the policy instruments approach in political studies and on the cultural-historical activity theory. It is used to study the relationships and changes of policy instruments and objectives of a major school development program in Taiwan launched in 2007. The group in charge of the program evaluated and changed both the objectives and instruments of the program in 2010. The direction of this transformation was from an approach based on competition and control towards an approach that emphasizes school autonomy, quality of curriculum and collaboration and learning between schools. The paper distinguishes three dimensions of policy instruments to analyze how the new orientation became embedded in the instruments used in the program implementation. The paper further suggests that policy learning can be analyzed in terms of remediation, that is, collective redesign of the system of instruments.
\end{abstract}

Keywords Educational policy $\cdot$ School development $\cdot$ Policy instruments $\cdot$ Tertiary artefact · Transformation of project instrumentality

\section{Introduction}

The classic book of Tyack and Cuban (1995) showed that the journey from educational policy discussion to what occurs in schools and classrooms is long, complicated and often unpredictable. To clarify this complexity we find it important to extend the discussion of educational policy interventions from analyses of discourses and texts to the relationship between talk and functional instruments of implementation used in reforms. In this paper we approach this problem through policy instruments. The policy instrumentality of a reform comprises different levels

Hongda Lin

hongda.lin@helsinki.fi

1 Center for Research on Activity, Development and Learning (CRADLE), Faculty of Educational Sciences, University of Helsinki, Siltavuorenpenger 1A, 00170 Helsinki, Finland 
of instruments, from verbally expressed objectives to tools of financing, control and planning, as well as procedures that allow and support local development and learning (see e.g., März et al. 2017; Hall 2017). The instruments of implementation are not neutral. They reflect the political and educational philosophies within which they emerged. It is therefore essential to analyze the logic embodied in the instruments. The interdependency and the compatibility between the reform objectives and the various policy instruments used in the reform are especially important. These relationships reveal basic and often hidden assumptions which can provide with a possibility to reconsider the dynamics of policy learning (Flanagan et al. 2011). To clarify the importance of these relationships we will analyze a transformation of the instrumentality of a major educational reform in Taiwan, the School Actualization Program (SAP).

This program was launched in 2007 by the Ministry of Education (MOE) to increase the number of high-quality senior high schools. All senior high schools in Taiwan were free to apply to this program. The Ministry nominated an expert group to plan, implement, and evaluate the program. In 2008 the group comprised nine university professors, six senior high school principals, one representative of the National Federation of Teacher Unions, and two civil servants from the MOE. Originally SAP was planned for the years 2007-2010 but has continued until now. It has become a more or less institutionalized way of developing secondary high schools in Taiwan: 210 schools participated in the program in 2016. SAP has established itself as a network of learning and innovation within the governance system of the Taiwanese educational policy (Miettinen 1999). This paper will analyze the transformation of the program in the years 2009-2010, when a second cycle of the program was planned and implemented and the policy instruments were significantly transformed.

In the international discussion of school development strategies, two ideal-typical alternatives may be distinguished (Hargreaves and Shirley 2009; Hodgson and Spours 2016; Sahlberg 2007). The first one is a market-based and top-down approach in which governments assign goals to schools in the form of standard test scores for different subjects, as well as measures and controls that achieve these goals. The results of testing are used in evaluation and funding of schools. They are also made public to allow the ranking of the schools, which constitutes a ground for the formation of an educational market. This is the dominant model adopted, for example, in the United States (see e.g., Ravitch 2013) and England (e.g., Hodgson and Spours 2014). However, various problems of this approach such as teaching for tests, curriculum narrowing and inhibition of developing new pedagogical solutions have been reported (see e.g., Madaus et al. 2009; Ravitch 2010).

An alternative strategy comprises bottom-up approaches based on trust in teacher expertise, school autonomy in developing curriculum and pedagogy as well as on collaboration between schools and other societal actors (see e.g., Tyack and Cuban 1995). The Finnish school governance has been used to characterize the second alternative. It uses neither standardized national tests nor inspection systems (Simola et al. 2013). The test results of schools are not publicly available, to prohibit the formation of an educational market. The schools are expected not only to implement the curriculum framework but also to develop their own curricula in response to 
local circumstances (Aho et al. 2006; Miettinen 2013; Sahlberg 2015). These two alternatives are ideal-typical. In many school systems, hierarchical regulation and autonomy are combined in various ways and correspondingly school development approaches are categorized in other and more elaborate ways (see e.g., Ball 1997; Hodgson and Spours 2016).

We shall, however, use these two ideal-typical alternatives to characterize the direction of changes that took place in SAP and its instrumentality in 2009 and $2010 .{ }^{1}$ We will study the SAP objectives as they are expressed in the policy documents, and analyze the set of instruments used in the implementation of the program. We will first introduce our theoretical framework and the concept of policy instrumentality. Then we will characterize the political context of the emergence of SAP in Taiwan. We introduce the five types of instruments and procedures included in the SAP instrumentality, and then the data and method of the study. The results of the analysis are presented: what problems the group members found in the SAP idea and objectives and in the tools and techniques used in their implementation, and what suggestions were made for improving them. Conclusions are drawn concerning the transformation of SAP and the role that remaking the policy instruments played in it.

\section{The theoretical framework: the policy instrumentality}

The developers of the policy instruments approach (Lascoumes and Le Galès 2007) find that policy studies have focused mainly on policy ideas, shared systems of belief, symbols, and neglected the study of concrete policy tools or instruments. They point out that "every instrument constitutes a condensed form of knowledge about social control and ways of exercising it" (Lascoumes and Le Galès 2007, p. 1). Therefore, a careful study of different instruments, techniques and tools is needed to understand political change. They also discuss differences between legislative, fiscal, contractual and communication-based instruments. However, they do not discuss the epistemological or psychological functions of instruments in policy making.

According to Cultural Historical Activity Theory (CHAT), human thought and activity is always mediated by cultural artefacts or mediational means (Vygotsky 1980; Cole 1996). The concept of the artefact refers to a man-made object that has a meaning and constitutes a part of our culture. Philosopher Marx Wartofsky (1979) drew a distinction between different kinds of artefacts. Among them, tertiary artefacts are alternative imaginative perceptual models, "a representation of possibilities which go beyond present actualities" (Wartofsky 1979, p. 209). Engeström (2007) characterized tertiary artefact as a 'where-to' type of cognitive artefact that is

\footnotetext{
1 Weber (1904 [1949], pp. 90-94) characterizes the function of an ideal type as a benchmarking device in social research as follows: "It is a scientifically formulated pure type (an ideal type) of a common phenomenon. (...) it is a conceptual construct (Gedankenbild) which is neither historical reality nor even the 'true' reality (...) It has the significance of a purely ideal limiting concept with which the real situation or action is compared and surveyed for the explication of certain of its significant components".
} 
used to orient to the future and to imagine and define alternative modes of activity. However, such visions must be complemented with tools, methods, plans, rules and forms of social collaboration (Miettinen and Virkkunen 2005). If this is not properly achieved, there is a risk that visions remain utopian rhetoric or an espoused theory unable to change or direct real activities (Argyris and Schön 1978).

Engeström (2007) suggests that different levels of concepts and tools "form integrated toolkits... tool constellations or instrumentalities" (p. 33). Each historically developed activity has a particular constellation of mediating artefacts, the relation of which needs to be analyzed in order to understand organizational change. The different instruments used in an activity may have different origins, therefore there is no guarantee that they are fully compatible with the vision provided by a tertiary artefact for the future. In an effort to change, the instruments and their relationships also change and evolve.

We find the policy instruments approach and the activity theoretical approach complementary. Both of them recognize that policy objectives are not pre-given and independent of means. There is no ready-made set of instruments from which a principal can select to achieve policy objectives. The instruments change and develop (Kassim and Le Galès 2010; Miettinen 2006). The former analyzes policy instruments to reveal "the changes in the relationship between the governing and governed, as well as various forms of managing" (Le Galès 2016, p. 513). The latter focuses on cognition and remediation, that is, use and redesign of concepts and instruments for learning and development of practices. We think this complementarity may also contribute to the research of policy learning. There are several conceptual frameworks of policy learning developed to account for policy change, innovation policy, functions of supranational governance, and knowledge utilization in policy making (e.g., Bennett and Howlett 1992; Lundvall and Borrás 1997; Radaelli 2008; Dunlop and Radaelli 2013). In order to reveal the constraints on and potentialities of public action, more empirical analyses of actual processes of policy learning are still needed (Uyarra et al. 2017; Moyson and Scholten 2018). In light of the complementarity of the two approaches, we find a focus on the transformation of policy instruments and their relationships in studying empirical data may meet this demand. In fact, Deutsch (1963), arguably the first one expressing the concern for policy learning, already implies that the policy learning can be observed in a process of recombination of artefacts, "Once combinational probability, rather than rigid determination, can be accepted as part of our intellectual frame of reference, it is not difficult to treat novelty and creativity as combinational phenomena" (p. 176). According to this idea, we will focus on the process of remediation, that is, a collective elaboration of an instrumentality, a whole set of interdependent mediational artefacts (Miettinen et al. 2012).

In analyzing the instruments of the SAP, their problems and how they were redesigned, we will utilize the complementarity of the two approaches. We will analyze the instruments both as means of learning and as means of government, and how these two are interconnected. To accomplish this, we will draw distinctions between three dimensions of each of the instruments: the objectual-cognitive dimension, government and control dimension, and form of instruction and accountability dimension (see Table 1). The objectual-cognitive dimension refers to how and by what 
concepts education is understood, and how the policy objectives become defined in the instruments. The SAP project is about improving the quality of school work. Consequently the ways in which curriculum, teaching and learning are understood and defined in the instruments are important-especially for the school agents who are required to take practical measures to improve school outcomes. Specifically we will analyze the meetings of SAP group, in which they recognized the problems and solutions, and registered the cognitive trail into the policy abstract. The government and control dimension is about what the principals (the SAP group and MOE) require schools and external experts to report, in order to assess and control the project activities and funding. The form of instruction and accountability refers to how the instructions and forms used in planning and reporting of the SAP are constructed. It has been proposed that performance indicators (indexes, measures, rankings) can be regarded as a particular type of policy instrument, a means of abstraction and simplification by transforming meanings expressed in word into figures (Le Galès 2016). We will analyze indicators not as independent instruments but as one possible form of reporting. We will analyze whether the instructions and forms used in SAP require planning and evaluation in the form of indexes and numbers, or whether they require and allow the presentation of verbal arguments concerning the measures of improvement and the use of cognitive means such as conceptual maps.

These three dimensions are interrelated: what is regarded as important is likely to be controlled and embedded in the instructions and forms. Using the three dimensions in analysis allows us to clarify the transformation of SAP instruments. We will analyze what changes were made in them as part of the transition from the first cycle (years 2007-2010) to the second cycle (years 2010-2013) of SAP and how the transformation of instruments influenced the developmental work in schools.

\section{The emergence of SAP and the instruments used in its implementation}

SAP is one of the main programs used by the Taiwanese government to realize its policy of extending the original 9-year basic education to 12 years. It aims to improve school quality by attracting senior high schools to join the program. A competitive grant was used as incentive to join. Prolongation of basic education has been planned by the government of Taiwan since 1980s. The government of the longruling Chinese Nationalist Party (Kuomintang) planned to add one-year vocational training to the 9-year national basic education in 1983 to support the economic growth of the country (Executive Yuan 1992, p. 31). This plan was transformed as a result of the political developments of the 1990s. A strong social movement launched by university professors, parents and citizens demanded an extension of education reform beyond economic growth and competition (Huang 1996). In response, the government formed the task group Education Reform Commission in 1994. In its report, the commission defined the right to learning as a 'basic right for human creativity' (Executive Yuan Education Reform Commission [EYERC] 1996, p. 6). The Democratic Progressive Party won the presidential and parliamentary elections of 2000 and 2001, ending the dominance of the Kuomintang in Taiwanese 
politics. The reform of 1983 was transformed into a vision to provide high-quality senior high-school education to students in all regions of Taiwan. However the choice of senior high schools by students and their families was dominated by the ambition of entering top schools by achieving a high rank in the national examination tests after junior high school. School choice in Taiwan was based on school rankings rather than the distance of school from home (Hsu 2002).

A starting point for SAP was a finding by MOE that Yilan County had a large number of high-quality schools. It therefore constituted an exemplary case for other regions in Taiwan: A sufficient number of high-quality schools will decrease the selection of schools on the basis of their rank. A ministerial letter given in 2007 defined three objectives for SAP (Ministry of Education [MOE] 2007):

1. Stimulate the learning capacity of senior high school teams and stimulate and speed up school actualization.

2. Increase the percentage of students registering in their nearest senior high schools.

3. Balance the regional development of senior high school education, in order to carry out 12-year basic education progressively.

These SAP objectives can be regarded as a vision for the future or a tertiary artefact of the SAP activity. However, the first objective in particular, with the term 'school actualization', was amenable to various interpretations. ${ }^{2}$ The project idea of using competitive grants as an incentive to become a high quality school seems to stem from the tradition of competition of schools ranking based on student test scores. The competitive grant is widely used in Taiwanese public policy, which partly explains its adoption in SAP. It is not easily compatible with the idea of balancing regional development, as will be seen later. The appendices of the ministerial letter provided five instruments of implementation, which are presented in Table 1.

There were no detailed instructions on how developmental measures should be defined in the twelve potential areas of school development. This led to rather long lists of titles of developmental measures in the School Developmental Plans (SDPs) to cover the 12 areas in a balanced way. The criteria for selection underlined the role of school principals heavily (40 points out of 100). The SAP expert group evaluated and scored the applications and MOE followed their suggestions in the decision to accept schools into the SAP. The expert advice system mobilized a number of people for the developmental work. The Ministry selected two experts for each school who visited the grantee schools twice a year. In 2008 there were 88 experts for 107 schools. They reported on the progress and the problems they encountered by using a form provided by the Ministry, which was sent to MOE and to the school that they advised.

\footnotetext{
2 The origins of the term 'school actualization' is unclear. One possibility is that it was drawn from the concept 'self-actualization' proposed by Abraham Maslow in his humanistic psychology (Maslow 1943).
} 


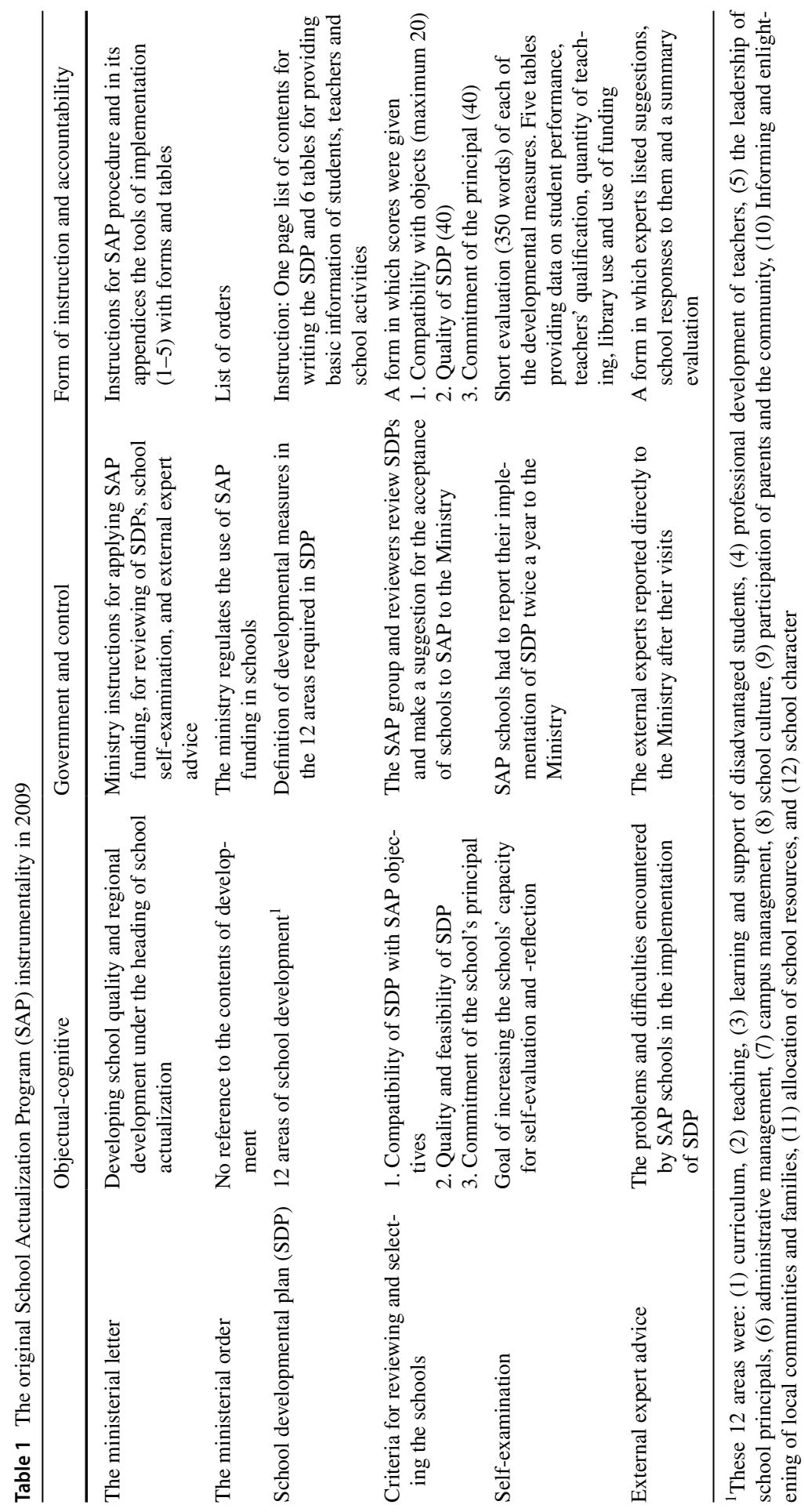




\section{Data and methods of analysis}

The main data selected to demonstrate the change of SAP instrumentality comprise the recordings of the discussion of two SAP meetings in June and July of 2009. Initially SAP was meant to be a three-year program for the years 2007-2010. To decide whether to continue SAP, MOE consulted the SAP group. In the June and July meetings, the group discussed the experiences of the first 2 years and a continuation of the program. It suggested revising the SAP by resolving the problems found and to advance the policy of 12-year basic education. The Ministry accepted the suggestion and decided to start the second cycle of SAP for the years 2011-2013. Before the meetings, an agenda and a memorandum written by a senior high-school principal who belonged to the SAP group were sent to the participants. The memorandum presented the alternative ways of stopping or continuing SAP. There was no internal exchange contested nor agreement made concerning the meeting items beforehand. These two meetings, therefore, constitute critical data for studying how the program, its objectives and instruments were changed.

The participants (20 in total) comprised five civil servants from MOE, six senior high-school principals, eight university professors, and one representative of the National Federation of Teacher Unions. They were selected by the Ministry to represent interests from different regions. These participants have collaborated with each other before the meetings in SAP implementation, for example, in reviewing SAP application and in visiting SAP schools. Before taking part in SAP, one professor and one principal also had participated in three other programs aiming to prepare the 12-year basic education policy since $1999 .{ }^{3}$ The Ministry paid to the participants an attendance fee. The meetings were chaired regularly by professor Peiying Chen who originally suggested the project and also functioned as the project investigator. She had not taken part in the policy projects that preceded SAP. We analyzed whether certain opinions were presented by a particular professional group: representatives of MOE, professors and school principals. That was not the case: opposite statements crossed the professional boundaries. ${ }^{4}$

The first meeting (29.06.2009) lasted $1 \mathrm{~h}$ and $59 \mathrm{~min}$. The second meeting (24.07.2009) lasted 1 h 38 min. Both meetings were voice-recoded without stopping. ${ }^{5}$ The recordings were transcribed. In the contract of the SAP research project, the Ministry agrees the usage of these transcripts for research purpose. The

\footnotetext{
3 These three programs are, comprehensive senior high school program, community high school program, and equal-quality high school program. They also focused on restructuring or improving the quality of senior-high schools. According to the reviewers, they did not generate significant outcomes.

4 The civil servants represented the Ministry could have steered the direction of discussion as the Ministry was the principal to decide whether to continue SAP or not. However, the civil servants did not dominate the conversation in the meetings. One of them asked, '...I kindly ask everyone present here to help us reflect the SAP implementation, I really want to change the current situation' (civil servant 3).

5 The voice recorder was placed in the middle of the meeting table. We however, were not able to documented data beyond voice, such as gestures, small talks between people sitting to each other and et cetera.
} 
project investigator of the SAP research project also agrees the use of the data in this research.

Four themes were selected for analysis in order to understand the SAP transformation. These themes were: (1) the problems with the original SAP idea and objectives, (2) the suggestions made to change the original SAP objectives, (3) the problems with the tools used in SAP, (4) the suggestions to revise the original tools and the ways in which they were used in SAP. The statements presented by the participants about each of these issues were recognized and coded (218 in total). Following the idea of a phenomenographic method (Marton 1986; Säljö 1994), categories of opinions concerning these themes were formed on the basis of the contents of the statements (see Tables 2, 3). The location of statements into categories were discussed between the authors. Whenever a statement was not self-evident member of a category, it was translated from Chinese into English to allow a joined decision by the two authors.

After the discussions, a workgroup of three members of the SAP group made a suggestion regarding the changes in the policy instruments. The changes were accepted by MOE for the second cycle of SAP. Accordingly, the second set of data comprises the SAP documents, orders, instructions and forms for applications and reporting (see Table 1). The changes made in the instruments (documents and forms) by the SAP group were shown by comparing the original documents from the year 2007 (MOE 2007) and the new documents, written in November 2009 (c.f. MOE 2009). We find this materialization of the ideas presented in the meeting discussions into the policy instruments to be a process of translating verbal ideas into policy practice.

\section{The problems and arguments of the original SAP objectives and the suggestions to resolve them}

Three main problems with the original SAP objectives were discussed in the meetings. Also suggestions to solve them were made. They are presented in Table 2.

The problem most frequently taken up was the contradiction between two SAP principles, pursuing school quality and balancing regional development of education. ${ }^{6}$ The arguments about how to resolve it reflected the two alternative positions concerning the direction of the project. The first one suggested accountability based on measurement, and the second one had a stronger focus on qualitative development of curricula and involvement of teachers in the development. Several participants lamented that under-motivated schools located in disadvantaged regions were selected to join the program to meet the principle of balancing regional development. 'Because of the principle of balancing regional development, schools with poor quality were able to join SAP... However their quality continues to be poor' (Professor 4). Some of the participants reflected on the possibility of applying the

\footnotetext{
6 These two principles are important values in the Taiwanese educational field. They can be found in the ninth and thirteenth articles of Educational Fundamental Act (1999).
} 
Table 2 The problems with the original objectives of School Actualization Program (SAP) and suggestions to resolve them

\begin{tabular}{|c|c|c|c|}
\hline $\begin{array}{l}\text { The problems with the original SAP } \\
\text { idea and objectives }\end{array}$ & $\begin{array}{l}\text { Number of } \\
\text { statements }\end{array}$ & $\begin{array}{l}\text { The suggestions and debates to } \\
\text { change the original SAP idea and } \\
\text { objectives }\end{array}$ & $\begin{array}{l}\text { Number of } \\
\text { statements }\end{array}$ \\
\hline \multirow{2}{*}{$\begin{array}{l}\text { 1. The contradiction between two } \\
\text { SAP principles: pursuing school } \\
\text { quality and balancing regional } \\
\text { development of education }\end{array}$} & 25 & $\begin{array}{l}\text { Debate whether to define the best } \\
\text { SAP schools by using ISO }{ }^{1} \text { identi- } \\
\text { fication procedures }\end{array}$ & 13 \\
\hline & & $\begin{array}{l}\text { Division of SAP into beginning } \\
\text { schools and advanced schools to } \\
\text { cover the principle of pursuing } \\
\text { school quality and the principle of } \\
\text { balancing regional development } \\
\text { of education }\end{array}$ & 35 \\
\hline $\begin{array}{l}\text { 2. Instrumental use of SAP funding } \\
\text { by the grant recipients for adver- } \\
\text { tisement and gaining reputation }\end{array}$ & 18 & $\begin{array}{l}\text { Creation of school character in } \\
\text { terms of objects, values and inter- } \\
\text { connected projects }\end{array}$ & 25 \\
\hline $\begin{array}{l}\text { 3. The vague meaning of "School } \\
\text { Actualization" }\end{array}$ & 10 & & \\
\hline
\end{tabular}

${ }^{1}$ ISO International Organization for Standardization

two principles in separate programs, but found even the separation conflictual. 'Will we obscure the direction of the original SAP if we have another program for pursing quality?' (Professor 1).

The same problem was raised in the discussion of the status and role of so-called star schools. 'Star school' is a term used in Taiwan to refer to those senior high schools that enroll the majority of high-academic-performance students. In addition to public funding, these schools often enjoy resources from their own networks of parents and alumni. Some of the participants felt that star schools should be included in the project. A principal, however, reminded the meeting that the original intention of SAP was to redistribute educational resources, to avoid competition based on test results and to reduce differences between schools. This conflict of views led to the discussion of how to recognize best schools. Some of the participants thought that the SAP schools should be certified by using ISO procedures of identification. 'We can use a procedure similar to ISO identification. The title of 'Quality School' will be granted only after a procedure of inspection on their implementation' (Civil servant 3). The concept and techniques of quality management have been applied in Taiwan educational administration, including the Department of Education in Taipei city. Two participants (a principal and a professor), however, warned that the adoption of these procedures might burden teachers instead of improving the schools in their core tasks: teaching and curriculum development. ${ }^{7}$ The participants eventually

\footnotetext{
7 A principal pointed out, 'Generally schools all have many programs ... This has two consequences. First, it is unclear how much a school has gained from different programs; second, many teachers and staff in schools are used to manage programs in their schools. This is done at the expense of the quality of teaching' (Principal 6).
} 
rejected the suggestion of adopting ISO or other standard identification procedures in the selection criteria.

In discussing the compatibility of the two principles, many participants thought that most of the SAP schools might not be able to improve their quality in a threeyear period. They correspondingly, made a suggestion to divide SAP applicants into beginning schools, and advanced schools which had participated in the first 3 years of SAP. 'The principle of pursuing school quality will be applied to the advanced school applicants' (Principal 4). This suggestion was included in the revised ministerial letter of SAP and to the instruments of implementation (see Table 4).

The second major problem with SAP was the instrumental attitude to SAP participation. Six participants reported that some of the SAP schools used the funding they received to advertise their reputation, and did not use it to improve curriculum and teaching. 'When I was driving on a highway, I saw a giant advertising billboard with 'XXX School is a Quality School selected by the MOE' written on it. How much did they spend on it?' (Professor 6). Two participants pointed out that the competition for program resources did not help schools to improve quality. In a testoriented culture the schools became motivated to use SAP resources to gain a higher position in the school rankings and to attract high-academic-performance students by using SAP grants as student fellowships. In their view, competitive grants tended to drive schools towards competition and prestige rather than towards improvement of school quality.

The third problem discussed was the vague meaning of the term school actualization used both in the title and the policy goals of SAP. Six participants found that the definition of the term was vague and unable to convey a clear direction of the development of schools. 'School actualization is such a big term. It seems to refer to every area of schooling' (Principal 2).

A solution suggested to address the problems of instrumental attitude and vague meaning of school actualization was to deepen the focus of development on curriculum, teaching and teacher involvement. Previously there were 12 areas of development in the instruction for SDP. The participants thought that priority should now be given to four of them. These four areas were (1) curriculum and teaching; (2) teacher professional development; (3) support of disadvantaged students; and (4) school character. School character refers to a specific focus, profile and objectives of a school, which also reflect its local circumstances and traditions. For the definition of the school character the schools were expected to define two or three projects in their SDPs. These projects were expected to be interconnected or in curriculum terms, integrated. The schools were expected to define the relationship of the projects to school objectives and to four areas of development. The participants thought that in this way the school orientation could be transformed from competition for resources into cultivation of competences. 


\section{The problems with the instruments used in SAP and the suggestions for their development}

Problems were found in the use of the five instruments of implementation and suggestions were made to improve them (presented in Table 3).

The most frequently raised problem was that External Expert Advice did not offer adequate support for SAP schools. 'The suggestions from experts usually had no impact on school practice... Lately during a visit, we found that the school didn't carry out any of our suggestions' (Principal 5). The participants also felt that external experts did not have sufficient understanding either of SAP objectives or of the school circumstances. To resolve this problem, it was proposed that expert advice should support schools to develop their autonomy and development skills: 'The key task of Experts is to encourage schools to develop the mechanism of self-management' (Professor 2). In addition, they agreed that the advanced schools should be able to decide whether they needed expert advice. This suggestion was integrated in the change of Ministerial Letter 2010.

The criteria for selection were discussed extensively. First there was a debate over whether summative evaluation should be added to the original criteria. Five speakers thought that a summative evaluation might force SAP schools to improve their quality. 'We will never make any quality schools if we don't have any opportunity

Table 3 The problems with the original tools used in School Actualization Program (SAP) and the suggestions for their development

\begin{tabular}{|c|c|c|c|}
\hline $\begin{array}{l}\text { The problems with the } \\
\text { original instruments used } \\
\text { in SAP }\end{array}$ & $\begin{array}{l}\text { Numbers of } \\
\text { statements }\end{array}$ & $\begin{array}{l}\text { The suggestions to revise the instruments } \\
\text { used in SAP }\end{array}$ & $\begin{array}{l}\text { Numbers of } \\
\text { statements }\end{array}$ \\
\hline $\begin{array}{l}\text { 1. External expert advice } \\
\text { did not offer adequate } \\
\text { support for SAP schools }\end{array}$ & 14 & $\begin{array}{l}\text { Redefinition of the function of exter- } \\
\text { nal expert advice to support school } \\
\text { autonomy and development skills }\end{array}$ & 9 \\
\hline $\begin{array}{l}\text { 2. Criteria for reviewing and } \\
\text { selecting schools did not } \\
\text { stimulate the development } \\
\text { of school quality }\end{array}$ & 11 & $\begin{array}{l}\text { Two criteria added for advanced schools: } \\
\text { the requirement of defining the intercon- } \\
\text { nection between projects and reporting } \\
\text { teacher involvement in them }\end{array}$ & 20 \\
\hline $\begin{array}{l}\text { 3. The ministerial order } \\
\text { hindered teachers" initia- } \\
\text { tive and the competitive } \\
\text { project funding bound } \\
\text { teachers to administrative } \\
\text { work }\end{array}$ & 11 & No changes suggested & - \\
\hline $\begin{array}{l}\text { 4. The } \mathrm{SDP}^{1} \text { forms did not } \\
\text { require head teachers to } \\
\text { communicate with teach- } \\
\text { ers and reviewers }\end{array}$ & 6 & $\begin{array}{l}\text { A new form added to SDP which requires } \\
\text { evaluation of previous projects. Require- } \\
\text { ment of defining of interconnection of } \\
\text { projects. Tables for reporting teacher } \\
\text { involvement in the projects }\end{array}$ & 9 \\
\hline $\begin{array}{l}\text { 5. School self-examination } \\
\text { did not support school } \\
\text { autonomy }\end{array}$ & 4 & $\begin{array}{l}\text { More focus on self-examination of curricu- } \\
\text { lum and projects. Peer learning between } \\
\text { schools added in school self-examination }\end{array}$ & 8 \\
\hline
\end{tabular}

${ }^{1}$ SDP School developmental plan 
to reject them' (Principal 4). Other participants opposed this stance and argued that the criteria should be a tool for supporting schools to develop their motivation. 'We should plan some developmental areas for schools which they can choose from, not ask them to leave' (Professor 6). After the debate, the majority of the participants agreed to add the requirement of defining the interconnection between projects and their relation to the four areas of development to the criteria. Another additional criterion suggested and approved was the involvement of teachers in the design and implementation of the projects. 'An application should have gone through discussion in school meetings, not just made up to apply for money' (Principal 5). Both of these criteria were added to the criteria for selecting advanced schools for the second cycle of SAP:

The third problem was found in using the Ministerial Order 'Directions of SAP Funding', which defined the scope and the purposes of funding. 'There are many restrictions on using SAP funds, which hinder teachers from participating. For example, we cannot give teachers any subsidies' (Principal 5). Teachers in SAP schools had participated in curriculum development in addition to their regular working hours. The order restricted SAP schools from financing these extra teaching and planning activities. Moreover, the participants found problems in the competitive grant system. The Taiwan government adopted it in the beginning of 2000s to reduce the education budget in a tightening financial situation. Senior high schools usually have to apply for these grants to maintain school finances. As a consequence, 'Many teachers and staffs in schools have to manage programs in their schools. This is done at the expense of the quality of teaching' (Principal 6). The system requires schools to produce application documents constantly, report the result of implementation, and raise their own matching grants.

The participants also found that the SDP form did not properly support the school development. The SDP required suggestions for one-year projects that remained disconnected from what had been done before. 'Schools presented new projects without discussing their previous projects' (Professor 4). The SDP form did not stimulate teachers' commitments nor did it support initiatives for school development. 'Many SDPs were written by head teachers just for applying for SAP. They started to think about what to do only after getting the grant' (Principal 2). Two major improvements were suggested to the SDP form. First, it should include evaluations of projects already realized. 'We should require schools to reflect on their previous projects... by this way we may know better how to support them' (Professor 4). Second, a separate additional form for SDP was suggested, in which the schools would reflect on the interconnections between the projects. Both of these suggestions were adopted into the new SDP form.

Four participants found that the standard tables used in School Self-examination did not support school autonomy. The Ministry may use the data collected from these tables to gain a general view of SAP annual implementation. This procedure, however, was largely disconnected from school developmental work. The participants suggested two solutions to improve this mechanism. First, taking local circumstances into account, 'We should allow each school to have its self-selected criteria to manage itself' (Professor 6). Second, expanding the procedure to include peer learning between the schools. 
Some SAP schools have done great work in their teaching, curriculum or other areas. We can pick one or two of these schools, and organize a workshop or a meeting to demonstrate their work. Other schools can then observe and learn with them. I think this is important, because everyone has their own interpretations of these SAP documents (Principal 5).

The requirement to report mutual learning between schools was added to the selfexamination report of the second cycle of SAP.

\section{Summary of the changes in the SAP objectives and instrumentality}

The summary of the changes made in the SAP instrumentality is presented in Table 4.

In discussing the possibility of continuing the program in 2009, the SAP group encountered and made visible both the ambiguous and contradictory nature of the program objectives as well as the limitations of the major instruments of its implementation. At the level of objectives the new metaphor 'school character' alone would have remained as ambiguous as 'school actualization' without connection to the changes made to the main instruments of implementation. The (cognitive) contents of these instruments expressed using operative concepts, such as four areas of development, integrated themes, projects, peer learning between schools, finally resolved the direction of the project.

In the debates on transforming the instruments of implementation there were different opinions. Some of the suggestions were inspired by ranking and competition: inclusion of star schools, summative evaluation and suggestion of using ISO standards in selection. After defining the problems of school ranking demonstrated in the separation of star school and non-star schools, the suggestions focused on quality of teaching and curriculum in terms of projects, strengthening teacher involvement and collaboration between schools became finally accepted.

Three substantial ideas were included in all key instruments of implementation: SDP, criteria of selection, self-examination and expert advice. The areas of development were reduced from 12 to 4 areas, which focused on curriculum, learning and teacher professional development and finding a school-owned character. Second, the developmental measures were defined in terms of a few interconnected projects, planned and realized by the teacher groups. They were also heavily emphasized in the forms for the evaluation of applicants. While originally 40 points (out of 100) was given to 'commitment of school principal', this criterion was replaced in the new criteria by 'quality of integrated projects and teacher involvement' (50), 'quality of self-examination' (20), and 'plan for peer learning between schools' (10). Finally, the inclusion of the requirement for collaboration between schools brought a new horizontal dimension to the development. It expanded the role of expert advisers into commentators in the interschool workshops.

The new instructions for writing SDP for advanced schools heavily underlined the definition of the few projects and their interconnection, preferably in the form of conceptual maps. As a consequence, the quality of the SDPs changed considerably. 


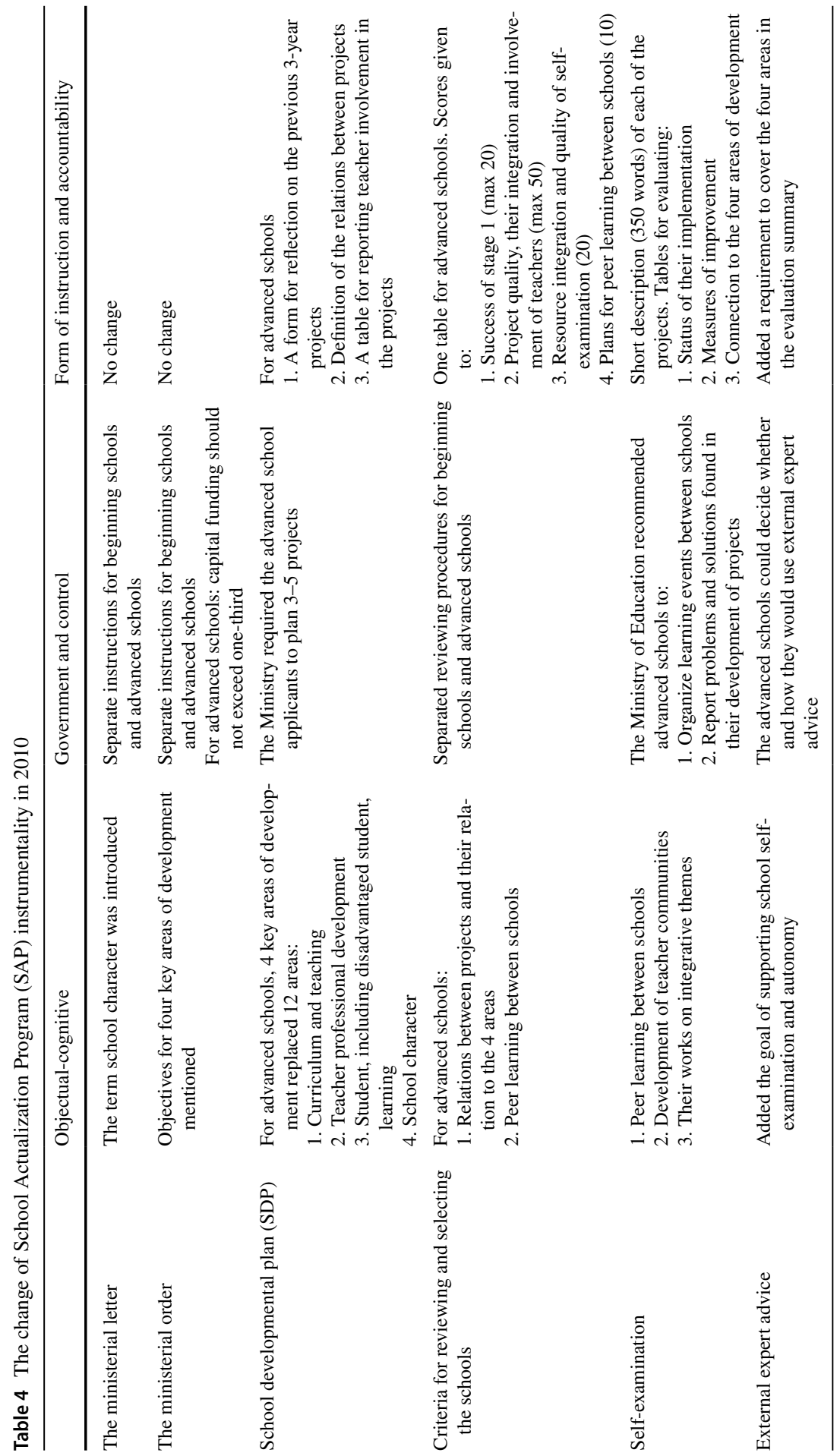


For example, the first application of the Huan Lien Boy School in 2007 was five pages long, including a list of developmental measures (8), each comprising two to three sentences. The plan for its second cycle in 2010 was 45 pages long and included several diagrams of school character and values, of the interrelationship between projects and their connection to four areas of development.

The participants in the SAP group characterized this change as 'deepening' or 'focusing' in the development of quality of education. In terms of form of instruction and accountability, a shift from lists of titles and quantitative data towards verbal and graphical presentation took place. In terms of government and control the quality of SDP and school activities became increasingly controlled by the SAP group and experts. The new vocabulary developed by the SAP group became a shared language and a new cognitive means of understanding for the SAP experts and schools of what it means to pursue school quality and balance regional development. The same vocabulary was embedded in the instruments that functioned as means of governing the SAP schools. The inventor of the new vocabulary and instrumentality, the SAP group, thus developed into a new hybrid agency steering the development of the secondary school system in Taiwan.

\section{Conclusions}

This paper studied a major educational reform program of secondary high schools in Taiwan (SAP) and specifically the transformation of the objectives and the instruments used in the implementation of the program at its turning point in 2009. The discussions in the program directing body, the SAP group, showed that the objectives of the program were ambiguous and amenable to different interpretations and were for this reason unable to direct the work of SAP schools. The SAP schools interpreted the program in terms of the schooling model prevalent in Taiwan. It corresponded considerably to the internationally dominant approach of school development based on centralized control, competition and school rankings. The competitive grant used by SAP represents this approach. Many of the schools joined SAP to get extra resources and to improve their reputation in order to be able to recruit high-quality students.

In addition, the SAP group found that the two central objectives of the program, raising the quality of schooling and balancing regional educational development, were contradictory. Because of the contradiction between SAP objectives and the ambiguity of the main concept used (school-actualization), the instruments of implementation largely directed the activity in the schools. In discussing how these policy instruments should be reformed or improved, an approach underlining competition based on objective measures confronted an approach trying to deepen the quality of teaching and learning. The changes realized in the instruments were a step taken towards a model which underlines the collaboration of teachers within schools, focus on curriculum contents, quality of teaching and learning from experiences of other schools. It is evident, that each new cycle of SAP will raise new problems and contradictions that will need to be resolved. For example, the ministerial 
order regulating teacher salaries was not changed even though it was seen as an impediment to developmental work. Also, the mobilization of teachers in the integrated projects will likely be incompatible with the timetables based on subjects and lessons.

Two main conclusions can be drawn from our analysis. It shows that we should not limit ourselves to studying the main ideas and verbally expressed objectives of a policy program. In the case of SAP they were too vague and not based on any educational theory, and therefore were unable to orient the works in the schools. Instead the operative concepts embedded in the instruments of planning and evaluation, that is, the four areas of development, school character, teacher involvement and projects, proved to be important. By drawing the distinction, we made the transformation of the instrumentality visible. The operative concepts became included in the instruments of evaluation by redefining on what issues the scores were centered. They were also accompanied by a change in the form of instruction and accountability in plans and reports: conceptual maps and verbal arguments were increasingly used. They directly caused changes in schools: the school communities were expected to define jointly the 'character' and values of the schools, projects and groups were formed, and interaction between the schools was required.

In terms of governance, the case also showed that SAP developed within the national education steered by the MOE into a new governmental institution covering 246 secondary schools in 2012 and hundreds of experts working with the schools. ${ }^{8}$ With the transformation of SAP instrumentalities, a considerable policy learning took place within the SAP group and in the schools involved. This development was accepted by the MOE. It therefore became complementary to the ministry's traditional governance based on competition and performance measures that supports efficiency in the provision of existing outcomes but does not stimulate educational innovations. This indicates that a single policy approach does not necessarily dominate a national education policy. There is a possibility of divergent developments. The development of a combination of governance approaches and mechanisms might constitute an important source of vitality in the development of the Taiwanese educational system.

What can our study offer to the discussion in policy learning research? Firstly, our analysis shows that the ambiguity and contradictions found in the policy object stimulated the SAP group to find ways to bring policy instruments to meet the objectives. As Heclo notes (1974), "politics finds its sources not only in power but also in uncertainty - men collectively wondering what to do [...]. Policy making is a form of collective puzzlement on society's behalf' (pp. 305, 306). SAP group eventually critically inquired the objectives in the meetings and redesigned the SAP instruments. This redefinition constituted a working hypothesis for the continuation and improvement of SAP. Thus the SAP group grew into an anticipatory agent who took responsibility of the transformation of the SAP instrumentality, and, therefore, a subject of policy learning. Ambiguity and contradiction in policy objects may enhance and strengthen the process of policy learning.

\footnotetext{
${ }^{8}$ There were 146 SAP schools in 2009 before the revision of SAP, and this number increased to 246 in the end of 2nd cycle of SAP in 2012. The number of SAP schools has grown over the years.
} 
Secondly, we find that the conceptions of policy learning based on cognitive psychology and the concepts of epistemic community and shared belief system tend to overestimate the intellectual or conceptual nature of object of policy making. Moyson and Scholten (2018) find that these conceptions may overlook the involvement of new actors in the development of interactive and participatory governance. Several recent studies also have been drawn to the uncertainty and dynamics inherent in policy processes (see e.g., Flanagan and Uyarra 2016; Dunlop 2017; Karlsen and Larrea 2017; Moyson and Scholten 2018). Our policy instrumentality framework based on the policy instruments approach and on activity theory provides an alternative way of conceiving these challenges. The concept of mediation in activity theory implies a systemic and interactive view of causality. The object and the set of means and instruments develop interactively. In transforming the means, also the object changes and becomes clarified. When the development of policy instruments is understood as remediation, it inevitably leads to novel forms of activity. In our SAP case, for instance, the new contents and form of the School Developmental Plan indeed radically extended and enriched the plans made by the schools. The policy objectives are likely to turn into practice, when the focus is directed to the system of interdependent and complementary policy instruments.

To develop further the instrumentality approach, it needs to be used to analyze different policy programs and projects. Comparative studies would advance the analysis of the coherence of policy objectives and instruments adopted to realize them. Comparative studies would also allow the characterization of typical sets of instruments involved in policy activities, such as planning, evaluation, self-examination, reporting etc. The specificities, requirements and forms of these types of instruments could then be analyzed. Furthermore, the use of policy instrumentality approach could be expanded by analyzing how a characteristic set of instruments is related to forms of government. In educational policy, quantitative measures typically serves centralized control and constitutes conditions for markets. In contrast, the instruments demanding arguments and conceptual articulation in the form of models and narratives serve the development of qualitative, substantial contents of activities. It is a challenge in which ways the necessary quantitative measures can be meaningfully combined with the qualitative instruments that support the values and contents expressed in the policy objectives.

The limitation of this article is the relative absence of the voices of politicians and teachers. The article could have included interviews of policy actors to present an updated view of the current state of SAP and its networks in the field. The analysis of the ways in which the schools and teachers actually used the instruments would have given a more complete account of the impact of the transformation of the policy instruments of the SAP project. Furthermore, an objective evaluation of SAP instrumentality would have required a more thorough historical analysis of the formation of SAP group, and its role in the current terrain of school development, as well as of the impact of SAP on educational policies in Taiwan. 
Acknowledgements Open access funding provided by University of Helsinki including Helsinki University Central Hospital.

Open Access This article is distributed under the terms of the Creative Commons Attribution 4.0 International License (http://creativecommons.org/licenses/by/4.0/), which permits unrestricted use, distribution, and reproduction in any medium, provided you give appropriate credit to the original author(s) and the source, provide a link to the Creative Commons license, and indicate if changes were made.

\section{References}

Aho, E., Pitkänen, K., \& Sahlberg, P. (2006). Policy development and reform principles of basic and secondary education in Finland since 1968. Washington, DC: World Bank.

Argyris, C., \& Schön, D. A. (1978). Organizational learning: A theory of action perspective. Reading, MA: Addison-Wesley.

Ball, S. J. (1997). Policy sociology and critical social research: A personal review of recent education policy and policy research. British Educational Research Journal, 23(3), 257-274.

Bennett, C. J., \& Howlett, M. (1992). The lessons of learning: Reconciling theories of policy learning and policy change. Policy Sciences, 25(3), 275-294.

Cole, M. (1996). Interacting minds in a life-span perspective: A cultural-historical approach to culture and cognitive development. In P. B. Baltes \& U. M. Staudinger (Eds.), Interactive minds: Life-span perspectives on the social foundation of cognition (pp. 59-87). Cambridge: Cambridge University Press.

Deutsch, K. W. (1963). The nerves of government: Models of political communication and control. New York, NY: Free Press.

Dunlop, C. A. (2017). The irony of epistemic learning: Epistemic communities, policy learning and the case of Europe's hormones saga. Policy and Society, 36(2), 215-232.

Dunlop, C. A., \& Radaelli, C. M. (2013). Systematising policy learning: From monolith to dimensions. Political Studies, 61(3), 599-619.

Engeström, Y. (2007). Enriching the theory of expansive learning: Lessons from journeys toward coconfiguration. Mind, Culture, and Activity, 14(1-2), 23-39.

Executive Yuan Education Reform Commission. (1996). Jiao yu gai ge zong zi yi bao gao shu (General consultation report for the education reform). Taipei: Executive Yuan.

Flanagan, K., \& Uyarra, E. (2016). Four dangers in innovation policy studies-And how to avoid them. Industry and Innovation, 23(2), 177-188.

Flanagan, K., Uyarra, E., \& Laranja, M. (2011). Reconceptualising the 'policy mix' for innovation. Research Policy, 40(5), 702-713.

Hall, J. B. (2017). "Governing by templates" through new modes of school inspection in Norway. Journal of Educational Change, 18(2), 161-182.

Hargreaves, A. P., \& Shirley, D. L. (Eds.). (2009). The fourth way: The inspiring future for educational change. Thousand Oaks, CA: Corwin Press.

Heclo, H. (1974). Modern social politics in Britain and Sweden: From relief to income maintenance. New Haven: Yale University Press.

Hodgson, A., \& Spours, K. (2014). Heavy fog in the channel: Continent cut off: reform of uppersecondary education from the perspective of english exceptionalism. European Educational Research Journal, 13(6), 683-698.

Hodgson, A., \& Spours, K. (2016). Restrictive and expansive policy learning: Challenges and strategies for knowledge exchange in upper secondary education across the four countries of the UK. Journal of Education Policy, 31(5), 1-15.

Hsu, M. (2002). Jie kai gao zhong zhi she qu hua de jie (Untie the problem of community senior high school). Jiao yu zheng ce lun tan, 2(2), 184-188.

Huang, W. H. (1996). Si yi ling jiao yu gai zao yu tui dong jiao yu xian dai hua (The 410 education reform and the modernization of education). In Tai wan jiao yu de zhong jian (pp. 157-161). Taipei: Yuan-liou Press. 
Karlsen, J., \& Larrea, M. (2017). Moving context from the background to the forefront of policy learning: Reflections on a case in Gipuzkoa, Basque Country. Environment and Planning C: Politics and Space, 35(4), 721-736.

Kassim, H., \& Le Galès, P. (2010). Exploring governance in a multi-level polity: A policy instruments approach. West European Politics, 33(1), 1-21.

Lascoumes, P., \& Le Galès, P. (2007). Understanding public policy through its instruments. Governance, 20(1), 1-14.

Le Galès, P. (2016). Performance measurement as policy instrument. Policy Studies, 37(6), 508-520.

Lundvall, B. Å., \& Borrás, S. (1997). The globalising learning economy: Implications for innovation policy. Luxembourg: Office for Official Publications of the European Communities.

Madaus, G. F., Russell, M. K., \& Higgins, J. (2009). The paradoxes of high stakes testing: How they affect students, their parents, teachers, principals, schools, and society. Charlotte, NC: Information Age Publishing.

Marton, F. (1986). Phenomenography-A research approach investigating different understandings of reality. Journal of Thought, 21(2), 28-49.

März, V., Kelchtermans, G., \& Vermeir, K. (2017). Artifacts as authoritative actors in educational reform: Routines, institutional pressures, and legitimacy in student data systems. Journal of Educational Change, 18(4), 439-464.

Maslow, A. H. (1943). A theory of human motivation. Psychological Review, 50, 370-396.

Miettinen, R. (1999). Transcending traditional school learning: Teachers' work and networks of learning. In Y. Engeström, R. Miettinen, \& R. Punamäki (Eds.), Perspectives on activity theory (pp. 325344). Cambridge: Cambridge University Press.

Miettinen, R. (2006). Epistemology of material transformative activity: John Dewey's pragmatism and cultural-historical activity theory. Journal for the Theory of Social Behaviour, 36(4), 389-408.

Miettinen, R. (2013). Innovation, human capabilities and democracy: Towards an enabling welfare state. Oxford: Oxford University Press.

Miettinen, R., Paavola, S., \& Pohjola, P. (2012). From habituality to change: Contribution of activity theory and pragmatism to practice theories. Journal for the Theory of Social Behaviour, 42(3), 345-360.

Miettinen, R., \& Virkkunen, J. (2005). Epistemic objects, artefacts and organizational change. Organization, 12(3), 437-456.

Ministry of Education. (2007). Gao zhong you zhi hua fu zhu fang an (School Actualization Program). The Official Letter of the Central Office, Number 0960065564.

Ministry of Education. (2009). Gao zhong you zhi hua fu zhu fang an (School Actualization Program). The Official Letter of the Department of Secondary Education, Number 0980519055.

Moyson, S., \& Scholten, P. (2018). Theories on policy learning: Existing approaches and future challenges. In N. F. Dotti (Ed.), Knowledge, policy making and learning for European cities and regions. From research to practice. Cheltenham: Edward Elgar Publishing.

Radaelli, C. M. (2008). Europeanization, policy learning, and new modes of governance. Journal of Comparative Policy Analysis, 10(3), 239-254.

Ravitch, D. (2010). The death and life of the great American school system: How Testing and choice are undermining education. New York, NY: Basic Books.

Ravitch, D. (2013). Reign of error: The Hoax of the privatization movement and the danger to America's public schools. New York, NY: Vintage books.

Sahlberg, P. (2007). Education policies for raising student learning: The Finnish approach. Journal of Education Policy, 22(2), 147-171.

Sahlberg, P. (2015). The Finnish lessons 2.0. What can the world learn from the educational change in Finland?. New York, NY: Teachers College Press.

Säljö, R. (1994). Minding action: Conceiving of the world versus participating in cultural practices. Nordisk Pedagogik, 14(2), 71-80.

Simola, H., Rinne, R., Varjo, J., \& Kauko, J. (2013). The paradox of the education race: How to win the ranking game by sailing to headwind. Journal of Education Policy, 28(5), 612-633.

Tyack, D. B., \& Cuban, L. (1995). Tinkering toward utopia: A century of public reform. Cambridge, MA: Harvard University Press.

Uyarra, E., Flanagan, K., Magro, E., Wilson, J. R., \& Sotarauta, M. (2017). Understanding regional innovation policy dynamics: Actors, agency and learning. Environment and Planning C: Politics and Space, 35(4), 559-568. 
Vygotsky, L. S. (1980). Mind in society: The development of higher psychological processes. Cambridge, MA: Harvard University Press.

Wartofsky, M. (1979). Models: Representation and scientific understanding. Dordrecht: Reidel.

Weber, M. (1949). Objectivity in social science and social policy. In E. A. Shills \& H. A. Finch (Eds., Trans.), The methodology of the social sciences (pp. 50-112). New York, NY: Free Press (Original work published 1904).

Yuan, Executive. (1992). Yan zhang yi zhi ye jiao yu wei zhu de guo min jiao yu di san jie duan ji hua shi di cha zheng bao gao (The report of examining the third phase of prolongation of national education embodied in vocational education). Taipei: Executive Yuan. 